\title{
Timurlularda Şehzade Eğitimi
}

\author{
Dr. Öğr. Gör. Mehibe ŞAHBAZ*
}

Atıf / @ - Şahbaz, M. (2018). Timurlularda Şehzade Eğitimi, Çukurova Üniversitesi Ilahiyat Fakültesi Dergisi, 18 (1), 313-328.

Öz- Timurlular Türk-Moğol unsurlarıyla yerli İran ve İslam kültürünün karışması sonucu ortaya çıkmıştır. Timurlular her ne kadar Çağatay geleneği başta olmak üzere Cengiz ve bozkır geleneğini sürdüren Türk teşkilatları, Arap ve Müslüman Türk devletlerinden ayrı bir yapı olarak karşımıza çıkmış olsa da Türk- İslam kültür ve geleneklerinin hâkim olduğu Maveraünnehir bölgesinde yetişmiştir. Timur iktidar meşrutiyetini ve hâkimiyet anlayışını ortaya koyarken Türk hâkimiyet anlayışı üzerine şekillendirmiştir. Diğer Türk ve Moğol Devletlerinde olduğu gibi Türk Cihan Hâkimiyeti anlayışını korumuştur. Timurlu Devletinin İslam dinini kabul etmesiyle geleneksel Türk hâkimiyet anlayışına uygun olarak gücünü doğrudan doğruya Allah'tan almaktaydı. Yeryüzünde Allahın gölgesi ve İslam peygamberinden sonra en yetkili bir makama sahip olarak kendine verilen bu makamın gücünü kullanarak halkını ve dini korumak için mutlak bir otorite olarak karşımıza çıkmaktadır. Timurlulardaki bu hâkimiyet anlayışı kendinden sonra halefleri zamanında devam etmiştir. Bu çalışmamızda da öncelikli olarak Timurluların nerede, ne zaman ve kim tarafından kurulduğu, Timur zamanında oluşturulan Timurlu devlet siyaseti gereği doğrultusunda Şehzadelerin (Mirzaların) eğitimi ele alınmıştır. Timurlular şehzadelerin ve hanedan üyelerinin eğitimine büyük önem vermişlerdir. Dolayısıyla bu görevi bir devlet görevi olarak kabul etmişler ve şehzadelere ve hanedan üyelerine doğumdan itibaren başlayan bir eğitim sistemi uygulamışlardır. Bu eğitim sisteminin nerede yapıldığı ve Şehzadelerin hangi süreçten geçtiği ve Şehzadelere tahsis edilen hocalar ve bu hocaların eğitim sürecinde şehzadeler üzerindeki etkileri incelenmeye çalışılmıştır. Mirzaların doğumları, tahta çıkışları, atabeylerin eğitim sürecindeki rolü ve görevleri ele alınmıştır. Ayrıca Timurlu hükümdarların ve şehzadelerin bilim, eğitim ve kültüre önem vererek hâkim oldukları topraklara başta Semerkant olmak üzere Herat, Şiraz, Tebriz gibi şehirleri ilim ve sanat merkezi haline getirmeleri ele alınmıştır.

Anahtar sözcükler-Mirza, Eğitim, Timurlu Devleti, Devlet Yönetimi, Atabey

\section{$\S \S \S$}

Makalenin gelişi: 24.01.2018; Yayına kabul tarihi: 12.06.2018

* Çukurova Ü. Atatürk İlke ve İnkılâpları Tarihi Bölümü, e posta: mevhibesavas@gmail.com (ORCID: 0000-0002-0597-925X) 


\section{Giriş}

Timur (Aksak Timur)Timurlu hanedanının kurucusu ve ilk hükümdarıdır (Babür, 1970:21). 25 Şaban 736 (8 Nisan 1336)'da Semerkant'ın güneyinde Keş Şehrin (Şehr-i Sebz)'de doğmuştur. (Şerefüddin Ali Yezdi, 2013:25). Babası bölgedeki Barlas kabilesinin Emiri Turagay'dı. Annesi Tekina Hatun'dur. Timur'un 1360 yılına gelinceye kadarki hayatı hakkında kaynaklarda herhangi bir bilgi bulunmamaktadır. İlk defa adından 1361 yılında bahsedilmeye başlanılan Timur, Çağataylılar ve Moğollar (Yücel, 1989:11) arasındaki çatışmalara katılmış ve sık sık taraf değiştirmiştir. Daha sonra kendisine yararı dokunacağı kişilerle akrabalık ilişkileri kurmaya gayret etmiştir. Müslüman bir ortamda yetişen Timur, Türk Moğol geleneklerini yaşatmaya devam ederek bu geleneğin yasalarını da ihmal etmemişti (Barthold, 1901:19). Dönemin tarihçilerinden olan İbn Arabşah Timur'un yasayı şeriata tercih ettiğini söylemektedir. Bu yüzdendir ki bazı ulema tarafından kâfirlikle suçlanmıştır (Aka, 1991:107).

Emir Timur'un hükümdar olmasından kaynaklanan geniş bir haremi bulunmaktaydı. Yazılı eserlerde hareminde on sekiz hatunu ve yirmi bir cariyesi bulunduğu bildirilmektedir (Nizameddin Şami, 1949:31). Emir Timur'un evliliklerinin birçoğunu siyasi sebeplerle yaptığı, çeşitli kabile reisleri ve hükümdarlarla evlilik yaparak hem askeri hem de siyasi gücünü artırma yoluna gittiği görülmektedir. Tarihi kayıtlarda on üç eşi hakkında bilgi bulunmaktadır (Şimşirgil, 2017:221). Hükümdarlık için yapmış olduğu on yıllık mücadeleden sonra 12 Ramazan 771 (9 Nisan 1370)'de Maveraünnehir'e hâkim olarak Semerkant'ta tahta oturdu. Timur'un başarısının en büyük nedeni bölgedeki kabileler arasındaki mücadeleler ve güçlü bir rakibinin olmayışıdır. İslami bir çevrede yetişen ve kendisi de Müslüman olan Timur eski Türk ve Moğol geleneklerine de bağlı kalarak yaşatmaya çalışmıştır (Barthold, 1997:15). Devamlı surette bu geleneğin oluşturduğu yasaya bağlı kalmıştır. Kendisinden sonra gelen torunları da bu yasayı tamamen bir kenara itmemişlerdi. O dönemin ünlü tarihçileri Timur'un halefi olan Şahruh'u şeriata bağlı mükemmel bir İslam hükümdarı olarak tanımlamaktadırlar (Aka, 1994:101). Şahruh zamanında şeriat hükümleri, Timurlu yasalarından üstün tutulmuşsa da bu yasalar tamamen bir kenara itilmemişti. Dönemin ünlü tarihçisi Arabşah, Şahruh'un dindarIığından bahsetmiş ise de Şahruh'un samimiyetinden şüphe etmiştir. Şahruh'un bir taraftan İslam kaidelerine bağlı olması bir taraftan da Timurlu devletinin törelerine bağlıı̆̆ Arabşah'ın şüphelenmesine neden olmuştur (Togan,1949:526). Bir defasında Şahruh torunu Mirza Mesud'un töreye aykırı hareket etmesinden dolayı tutuklatmıştır. Hatta Şahruh beylerbeyi Firuzşah'ı 
bir toplantıda Timurlu töresine uymadığı için de eleştirmiştir. Uluğ Bey ise devlet idaresinde dedesini taklit ederek Moğol beylerinden olan Duglat Hudaydad'ı bizzat huzuruna getirterek yasanın kaidelerini öğrenmiştir (Barthold, 1997:39). XV. yüzyıla gelindiğinde Timur devletinde hâkimiyet anlayışında değişiklikler olmuştur. XV. yüzyılın ikinci yarısından itibaren hükümdarlar hâkimiyetlerini sağlamak veya sürdürmek için dini makamlara daha fazla önem vermeye başlamışlardır (Yüksel, 2009:39). Örneğin Mirza Abdullatif, Ebu Said ve oğlu Sultan Ahmet gibi isimler şeriatın tesiri altında hareket etmişlerdir (Clavijo, 1993:42). Şahruh zamanında yasa aleyhinde aşırı muhalefet başlamış ve İslam tesiri artmış olsa da yasanın tesirleri Timur Devleti'nin yıkılışına kadar devam etmiştir (Aka, 2012:178). Hatta Timurlularla birlikte Hindistan'da da tesirini devam ettirmiştir. Moğollardaki "gökyüzünde bir tane güneş ve ay varken, yeryüzünde nasıl iki hâkim olabilir" fikri, Timur zamanında da devam etmiştir. O dönemin tarihçilerinden biri ona "dünya iki hükümdara yetecek kadar geniş değildir. Tanrı nasıl bir tane ise, Sultan da bir tane olmalıdır" sözünü isnat etmiştir. Yine ondan "bir kadının iki kocası olamayacağı gibi, bir devletin de yalnız tek hâkimi olmalıdır" sözünü söylemektedir. Bu hâkimiyet anlayışı Timur'un soyundan gelen Babür'ün kaleme aldığı eserinde de yer almaktadır. O, "aynı zamanda bir vilayette iki padişah ve bir askere iki kumandan karışıklık ve haraplığı icap ettiren fitne ve perişanlığa sebep olur" ve "İki Padişah bir iklime sığmaz" sözleri ile merkeziyetçi hâkimiyetin gereğine işaret etmiştir (Barthold, 1946:201). Baykara'nın ölümünden sonra, Herat'ta oğulları Bediüzzaman Mirza ile Muzaffer Mirza'nın müşterek olarak tahta oturmaları karşısında "bu, garip bir işti. Hiçbir zaman padişahlıkta ortaklık duyulmamıştı" diyerek hayretini gizleyememiştir. Timurlulardaki veraset sistemi Türklerdeki veraset sistemi anlayışıyla hemen hemen aynıydı. Ülke hükümdar ailesinin ortak malı kabul edilmiştir (Mansura, 1984:615). Ancak Timur, Cengiz soyundan olmadığı için emir unvanını kullanarak Cengiz ailesinden birisini şeklen de olsa hükümdar yapmıştır (Nizameddin Şami, 1949:21). Timurlularda da daha önceki Türk devletlerinde olduğu gibi belli bir veraset sistemi yoktu. Ülke toprakları hükümdar ailesinin ortak malı sayılırdı. Devletin başında bulunan hükümdardan başka, devlet yönetiminde hanedana bağlı diğer erkek üyeler de görev alırdı. Mirza denilen bu hanedan üyeleri, eyaletlere gönderilirlerdi. Timur, devlet yönetiminde hem Türk idari geleneklerini hem de Cengiz Yasası'nı da kullanmıştır (Tüzükat-ı Timurin ve Cengiz Yasası, 1974:41). Daha sonraki hükümdarlar döneminde İslamiyet'in kabulüyle birlikte devlet yönetiminde, İslami kurallar da etkili olmaya başlamıştır. Mutlak hâkimiyete inanan Timur, kurultaya önem vermemekteydi. Şayet bir şey yapmak 
isterse kendisini haklı göstermek için Kuran-ı Kerimden ayetler naklederek haklılığını ispatlamaya çalışırdı. Ulemanın Timur'la sohbetinde her zaman dikkatli olması gerekiyordu. Din onun elinde daha çok siyasi amaçlarına ulaşabilmek için kullandığı bir alet olmuştur (Togan, 1932:77). Timur'un nazarında ulemanın kendisine bağlılığından ziyade, beyler ve kabilelerin bağlılığı önemliydi (Togan, 1972:81). Moğol geleneklerine bağlı bir Müslüman olan Timur, Cengiz Han ile akrabalığa ayrı bir önem vermekteydi. 1370 yıllarında Kazan Han'ın kızı Saray Mülk hanımı nikâhına alarak Küregen (Güvey) lakabını almıştır (Nizameddin Şami, 1949:36). Daha sonar Timur'un bu kadından bir oğlu dünyaya gelmiş ve ölene kadar bu çocuğu yanında taşımıştır. Böylece Cengiz soyundan birini "Han" olarak yanında yer almasını istemiş kendiside "Beğ” unvanını almıştır. Uluğ Beğ'de dedesinin takip ettiği politikayı izleyerek Cengiz soyundan gelen bazı şahısları hanlık tahtına oturtmuştur. Şahruh döneminde ise böyle bir uygulamaya gerek görülmemiştir (Aka, 1994:11). Timurlu devleti ve bu devletin Türk ve Moğol devletlerinde olduğu gibi Türk Cihan Hâkimiyeti anlayışını koruduğu üzerinde durulduktan sonra Timurlu Devletinin başına geçen Sultanların kronolojik sırasını vermemiz Timurlulardaki şehzade eğitimini anlatmamız açısından yerinde olacaktır. Başlıca Timurlu Hükümdarları:

1370- Timur

1405- Halil Sultan (1409'a kadar)

1405- Şahruh (1409'a kadar yalnız Horasan Bölgesinde hâkim)

1447- Uluğ Bey

1449- Abdüllatif

1451- Ebu Said

1469- Ahmed

1494- 1500 Mahmud b. Ebu Said

Uluğ Bey'den sonra Horasanda hüküm süren Timurlu Sultanlar

1449- Babür

1457- Mahmud b. Babür

1459- Ebu Said

1469- Yadigâr Muhammed

1470- Hüseyin Baykara

1506- Bediüzzaman 


\section{Timurlu Şehzadeler (Mirzalar)'ın Eğitimi}

Timurlularda hükümdar çocuklarına verilen Mirza ismi Farsça kökenli olup hükümdarın soyundan gelen anlamında mir-zade veya emir-zade isminin kısaltılmış şekliydi. Türkçede "Ağa" ismine karşılık gelmekteydi (Levy, 1993:129). Mirza ismi şehzadeye karşılık gelen bir isimdi. Bundan dolayıdır ki mirzalar babalarının sağlığında eyaletlere (sancağa çıkma) tayin edilirlerdi. Buralarda mirzalar bütün askeri ve idari işlerde yetiştirilmekteydi. Bir hükümdarın bilmesi gereken her şey öğretilirdi (İbn Arabşah, 1285:46). Mirzalar eyaletlere ortalama on veya on beş yaşlarında gönderilirdi. Kendilerinin çok iyi bir şekilde yetişmesi ve yardım etmeleri içinde yanlarına tecrübeli atabeyler verilmekteydi. Mirzaların gönderildikleri eyaletlerde saray erkânı da yer almaktaydı (Şerefüddin Ali Yezdi, 2013:246). Timur devletinde mirzalar ve hanedan üyelerinin eğitimi bir devlet görevi sayıldığından bu kimselerin yetiştirilmesine anne babanın karışmasına izin verilmezdi (İbn Arabşah, 1285:56). Doğum vakti geldiğinde şehzadeyi doğuracak olan kadın saraya getirilip bakımına özen gösterilirdi. Mirza (Şehzade) dünyaya geldikten sonrada annesinden alınırdı (Barthold,1997:29). Her türlü bakımı ve eğitimi için hükümdar hanımlarından birinin gözetimi altında saraydaki özel yetiştiriciler tarafından büyük bir özenle büyütülürdü. Dönemin meşhur âlimlerden dini ve akli ilimler olmak üzere çeşitli dersler aldırılarak en iyi şeklide yetişmeleri sağlanırdı (Şerefüddin Ali Yezdi, 2013:450). Diğer Türk devletlerinde olduğu gibi geleceğin muhtemel hükümdarı olan mirzalar belli bir yaşa geldiklerinde de idari konularda tecrübe kazanmaları için güvenilir ve seçkin emirler arasından seçilen bir atabeyin denetimine bırakılırdı (Şerefüddin Ali Yezdi, 2013:459). Mirzaların herhangi bir eyalet merkezine gönderilmesinde herhangi bir fark gözetilmemiştir (Aka, 1991:107).

\section{2. Şehzadelerinin Dünyaya Gelişi ve Düzenlenen Şenlikler}

Timur kendisinden sonra gelecek olan haleflerine çok önem vermiştir (Kafalı, 338). Timurlulardaki veraset sisteminde taht hükümdar ailesinin ortak malı kabul edildiği için Timurlu Hanedanlığının devamı için erkek çocuğuna sahip olmak oldukça önemliydi (Şerefüddin Ali Yezdi, 2013:459). Bu yüzdendir ki şehzadelerin doğumları sadece sarayda değil Timurlu devletinin hâkim olduğu her yerde sevinçle kutlanırdı. Şehzadelerin doğumlarında kutlamalar sarayda yapılırdı (İbn Arabşah, 1285:46). Şehzadelerin doğum haberi hükümdara verildiğinde hükümdar habercileri çeşitli hediyelerle ödüllendirirdi. Nitekim Timur'un torunlarından Muhammed Taragay yani Uluğ Beğ dünyaya geldiğinde 16 Nisan 1384 perşembe günü Mardin, Timur'a teslim olmuştu (Clavi- 
jo, 1881:248). Timur'un hanımı Saray Mülk Hanım Sultan iye'den Uluğ Beğ'in doğum haberi için Mardin'e bir elçi göndermişti Ancak elçi Mardin'e şehir kuşatıldıktan bir gün sonra ulaşabildi. Bu kutlu haberi bir gün sonra alan Timur doğumu kutlamak için şehir ahalisine aman vererek alınacak olan savaş tazminatından da vazgeçmiştir (Barthold, 1997:41. Ulu Beğ 'e önce Muhammed Taragay ismi verilmiş ise de daha sonraları Uluğ Beğ adının kullanımı ağır basarak kullanılmıştır. (Barthold, 1997:40).

Timurlularda şehzade doğumları sonrası yapılan merasimlerle ilgili pek fazla bilgi bulunmamaktadır (Babur, 1970:46). Kaynaklardan edindiğimiz bilgilere göre şehzadeler dünyaya geldikten sonra doğum şenlikleri düzenlenirdi (Şerefüddin Ali Yezdi, 2013:473). Bu şenlikler düğün havasında gerçekleşir şenliğe katılanlar şehzadeye para ve armağanlar sunardı. Mirzaların her hangi dönemde doğması önemli değildi. Çünkü Timurlu sarayında doğan her şehzade çok önemliydi (Togan, 1972:77). Ayrıca şehzadelerin doğumları gerçekleşir gerçekleşmez şehzadeye tayin edilen atabey ve atabey'in hanımı olan sütannesinin adları da defterlere kaydedilirdi (Şerefüddin Ali Yezdi, 2013:458). Nitekim Timur'un farklı hanımlarından dünyaya gelen Uluğ Beg ile İbrahim aynı yıl (1384) dünyaya gelmişti. İbrahim Bey’in yaşadığı yerde eserini yazan o dönemin ünlü tarihçisi Şerefüddin Ali Yezdi eserinde İbrahim'in doğumuna geniş bir yer vermiştir. Mirza İbrahim'in dünyaya gelmesiyle hemen yanını bir atabey ve atabeyin hanımı olan sütannesinin adlarının defterlere kaydedildiğini bildirmektedir. (Barthold, 1997:40).

\section{1. Şehzadelerin Çocuklukları ve Eğitim süreçleri}

Timurlularda Şehzade Eğitimini anlatırken Timurluların yaptırmış olduğu saraylar hakkında da bilgi vermemiz yerinde olacaktır. Çünkü şehzadelere verilen ilk eğitim Timurlu sarayında verilirdi (Şerefüddin Ali Yezdi, 2013:473). Ayrıca bu sarayların bir başka özelliği de şayet mirzalardan herhangi biri baş kaldırıp hâkimiyeti ele geçirirse bu saraylardan birinde tahta oturur, taht mücadelesinde yenik düşerse de başını burada kaybederdi (Şerefüddin Ali Yezdi, 2013:459). Timur birçok yerde çeşitli saraylar inşa ettirmiştir. Bilhassa da Semerkant ve yakınlarında farklı şekillerde muhteşem saraylar yaptırarak sarayın iç duvarlarına da kendisinin portrelerini çizdirmiştir (Yüksel, 2017:289). Bununla da kalmayarak hanımları, çocukları ve torunlarının resimlerini çizdirmesinin yanı sıra çeşitli hükümdarların, âlimlerin, önemli şahsiyetlerle olan görüşmelerini ve sohbetlerini, askerlerini, av ve savaş sahnelerini tasvir eden resimlerini de saraylarının çeşitli yerlerine tasvir ettirmiştir (Nizameddin Şami, 1949:51). Timur'un sarayları şato şeklinde değildi. Timur tara- 
fından yaptırılan Gök Sarayı köşkünde Timur çok az bulunmuştur. Saray Timur ve halefleri döneminde daha çok devlet hazinesi binası ve hapishanesi olarak kullanılmıştır (Yüksel, 2017:289). Diğer Türk devletlerinin yapı olarak sahip olduğu saraylardan farklılık arz eden Timurlu sarayında mirzaların ve hükümdarla ilk eğitim verilirdi. Timurlu sarayında doğan hanedan üyesine mensup her çocuk için özel daireler ayrılır yanlarına bu çocukların ihtiyaçlarının ve güvenliğinin sağlanması için anneleri ile dadıları bulundurulurdu (Yüksel, 2017:287). Şayet bu çocuklar şehzade ise çocuğun bakımı ve eğitimi için atabey ve atabey'in hanımı sütannesi tayin edilerek şehzadenin sancağa çıkma vakti gelene kadar bütün sorumluluğu alırlardı. Gerek hükümdar gerekse mirzaların maiyetinde Yasavul, İçki, Nöker ve Çehre adı verilen saray görevleri hizmet etmekteydi (Aka, 1994:192). Bu süre içerisinde şehzadeler belli yaşa gelince eğitimleri için hocalar tayin edilirdi. Bu süre içerisinde şehzadelere belli başlı dersler (Kuran, Tarih, Coğrafya, Farsça vs.) dersler verilmekteydi. Şehzadeler (Mirzalar) eyalet merkezlerine gönderilirken yanlarına atabeyler verilirdi. Şehzadeler gittikleri eyalet merkezlerinde aynen devlet merkezindeki saray ve idari teşkilatını hiç değiştirmeden kurardı (Nizameddin Şami, 1949:51). Burada bağımsız bir hükümdar gibi hareket ederek bölgeyi idare ederdi (Aka, 1994:186). Şehzadeler almış oldukları ilk eğitimlerinin ardından takriben 9-12 yaşlarına geldiğinde büyük şenlikler düzenlenerek sünnet olurlardı. Bu sünnet törenleri saraylarda büyük bir düğün havasında gerçekleşirdi (Babur, 1970:66). Bu şenliklerde bu eğlenceler sırasında dini bakımdan yasak olan davranışlarda bulunulurdu. Şeriatı savunan bazı ulema kesimini bu durum rahatsız etmekteydi. Timur'dan çekinen ulema bu rahatsızığını dile getirememiş ama Uluğ Beğ döneminde ise ulema rahatsızlıklarını dile getirmekten çekinmemiştir (Clavijo, 1993:62). Nitekim Uluğ Beğ'in en küçük oğlu Abdülaziz'in sünnet düğünü dolayısıyla Semerkantlıların yükümlülüklerini bağışlamıştır. Devletin ileri gelenleri ve halk tabakasından bazı kişilerin Kan-ı Gil düzlüğünde şarap içmeleri üzerine dönemin muhtesiplerinden Seyyid Aşık, Uluğ Beğ'e şu sözleri söylemiştir. "Sen Muhammed'in dinini mahvederek dinsizlerin dinini getirdin” demesi üzerine Uluğ Beğ sinirine güçlükle hâkim olarak "Sen Seyitlerin halefi ve ilim sahibi olarak tanınıyorsun artık yaşlandın ve galiba işkence içinde ölerek şehit olmak istiyorsun ve bunun içinde kaba lakırdılar kullanıyorsun, fakat ben senin istediğini yerine getirmeyeceğim" demiştir (Aka, 1997:109). Şahruh döneminde Şehzadelerin eyaletlerin merkezlerine gönderilme geleneğinden vazgeçildiğini görmekteyiz. Nitekim Şahruh döneminde Mirzaların yetiştirilmesine Timur'un döneminde olduğu gibi yeterince özen 
gösterilmediğini görmekteyiz. Şahruh döneminde Abdurrahman ve Abdülaziz babalarının yanında Semerkant Sarayında yetişmişlerdi (Yüksel, 2009:35).

\section{2.Şehzadelerin (Mirzaların) Yetişmesinde Atabeylerin Önemi ve Mirzaların Cezalandırılmaları}

Timurlularda geleceğin hükümdarları olacak olan Mirzaların her alanda yetişmesi için yanlarına özel bir yetiştirici Atabey verildiğinden daha önce bahsetmiştik. Geleceğin hükümdarı olacak veliaht mirzanın eğitimi ile diğer mirzaların eğitimleri arasında herhangi bir fark yoktu. Hatta mirzalarda olduğu gibi kız çocuklarının eğitimine de önem verilmekte onlara da (Ateke) adı verilen özel yetiştiriciler tayin edilmekteydi (Nizameddin-i Şami, 1949:63). Atabeyler mirzaların her türlü hareketinden sorumlu tutulmaktaydı. Ancak bazı zamanlar mirza ile atabeyler arsında da anlaşmazlıklar meydana gelmekteydi. Mirza Halil Sultan ile Hudaydad arasında olduğu gibi Uluğ Beğ ve atabeği arasında da bazı anlaşmazlıklar meydana gelmiş ve Uluğ Beğ babasına atabeyi hakkında şikâyette bulunmuştur (Barthold, 1997:70). Bunun üzerine Şahruh durumu incelemek için büyük emirlerinden Seyyid Ali Tarhanı teftiş için Semerkant'a gönderdi. Yapmış olduğu incelemeleri sonrası Seyyid Ali Tarhan, Şah Melikin ülkeyi çok iyi idare ettiğini ve Uluğ Beğ'e faydalı öğütlerde bulunduğunu ancak bu öğütlerin mirzanın gururuna dokunduğunu ve bu durumdan da bazı kötü düşünceli insanların faydalandığını bildirmiştir (Barthold, 1997:71). Atabeyler mirzaların merkeze karşı herhangi bir isyan girişimini de engellemekle görevliydiler. Mirzalar herhangi bir şekilde isyan çıkarmaya kalkar veya kendi aralarında bir anlaşmazlık baş gösterirse bu duruma ancak sülalenin başında bulunan bir kimse yani hükümdar müdahale edebilirdi (Tüzükat'ı Timurin ve Cengiz Yasası, 1974:91). Bu duruma en güzel örnek bir av sırasında atından düşüp ve sonrasında akli dengesinde bozukluk oluşan Miran şahın bulunduğu eyalet sancağında takınmış olduğu zalimce tutumları üzerine bizzat hanımı tarafından Timur'a şikâyet edilip duruma Timur'un müdahale etmesidir (Aka, 1994:188). Bu gibi hallerde mirza, çoğu zaman dayak atılmak suretiyle cezalandırır ve başka bir yere gönderilerek nakle tabi tutulurdu. Mirzaların cezalandırılmaları suçlarına göre dayak atmak, gözlerine mil çekmek veya öldürülmek gibi cezalandırma usulleri vardı (Clavijo, 1881:36). Şehzadelerin kanını akıtmak töreye aykırı olduğu için hanedan üyeleri yay kirişi ile boğularak öldürülürdü (Halaçoğlu, 1995:6). Ancak Timur döneminde mirzalara ölüm cezası verilmemişti (Nizameddin Şami, 1949:71). Timur, genellikle mirzaların suçunu görmemezlikten gelir veya zorunlu durumlarda onlara hafif cezalar vermeye çalışırdı. Bu cezalandırma şekilleri genelde sopa 
attırmak, huzuruna belli bir süre kabul etmemek gibi hafif cezalardı. Ancak kendisinden sonra halefleri döneminde ölüm cezaları verilmeye başlanmıştır (Nizameddin Şami, 1949:51). Timur mirzaların suçunu genellikle mirzaların atabeylerine bağlardı. Çünkü atabeylerin görevi mirzaları bu suçlardan alıkoymaktı (Şerefüddin Ali Yezdi, 2013:322). Timur zamanın da yaptırılan Gök Saray devlet hazinesinin saklandığı yer olmasının yanında aynı zamanda hapishane olarak da kullanılmaktaydı. Bu sarayın bir başka özelliği de şayet mirzalardan herhangi biri baş kaldırıp hâkimiyeti ele geçirirse burada tahta oturur, taht mücadelesinde yenik düşerse de başını burada kaybederdi (Şerefüddin Ali Yezdi, 2013:459). Daha sonraki dönemlerde falan mirzayı Gök Saraya çıkardılar sözü o mirzanın öldürüleceği anlamına gelmekteydi (Aka, 1991:117). Atabeyler'in mirzaların başa geçmelerinde büyük rolleri vardı. Kimi zaman da mirzalara kötü örnek olmuşlardır. Timurlu Şehzadelere (Mirzalara) atabeylik yapmış olan dönemin kıymetli atabeyleri şunlardır. Şahruh'a Alaaddin Alike Kükeltaş, İbrahim'e Emir Osman Abbas, Uluğ Beğ'e uzun bir süre Emir Şah Melik, Halil Sultan'a Emir Yahya'nın atabeylik yaptığı bilinmektedir (Aka, 1991:108).

\subsection{Mirzaların Almış Olduğu Dersler}

Timurlularda Şehzadeler (Mirzalar) geleceğin hükümdarı olacağı için dönemin meşhur âlimlerinden hem akli hem de dini ilimler olmak üzere çeşitli dersler alarak en iyi bir şekilde yetişmesi sağlanırdı (Thomas, 1985:34). Mirzalara dini ilimler olarak nitelendirdiğimiz Kur'an, Kıraat, Tefsir, Hadis ve Fıkıh gibi ilimler okutulmaktaydı. Bu dersleri okutan büyük âlimler arasında Seyyid Şerif Cürcani, Taftazani, Muhammed Cezeri, Hoca Abdülmelik Semerkandi gibi kişiler yer almaktadır (Yüksel, 2017:65). Mantık, Felsefe, Kelam, Fıkıh gibi derslerinin yanı sıra Astronomi, Matematik, Tıp, Tarih, Edebiyat, Resim, Mimari, Arapça, Farsça gibi dersler verilmekteydi. Yaklaşık 137 yıl Maveraünnehir ve Horasan bölgelerinde hâkimiyetini sürdüren Timurlular döneminde bilim ve kültür her alanda altın devrini yaşamış âlimlere, şeyhlere ve seyitlere gereken önem ve saygıda kusur edilmemiştir (Yüksel, 2009:64). Ayrıca da geleceğin hükümdarı gözüyle bakılan mirzalara idari konularda tecrübe kazanmaları için bu alanda da dersler verilmekteydi (Babür, 1970:56). Timur Semerkant da bilimsel ve kültürel bir ortam hazırlamıştı (İbn Arabşah:1285,35). Mirzalar içerisinde böyle bir ortamda yetişen en şanslı çocuğu küçük oğlu Mirza Şahruh idi. Şahruh doğduğunda Timur Çağatay tahtına oturmuş ve iktidarlığını sağlamlaştırmıştır (Şerefüddin Ali Yezdi, 2013:473). Bu yüzdendir ki onun yetiştirilmesi ve almış olduğu eğitim diğer mirzalardan farklı olmuştur. Şahruh Se-

ÇÜiFD, 2018, cilt: 18, sayı: 1, ss. 313-328 
merkant da toplanan âlimlerin bizzat eğitiminden geçmişti. Birçok tartışma meclislerinde bulunarak kendisini ilmi yönden geliştirmiş̧i (Ibn Arabşah, 1285:45). Böyle bir ortamda almış olduğu eğitim ileride Şahruh'un âlimleri, din adamlarını, sanatkâr ve şairleri özenle himaye etmesinde büyük bir etken olmuştur. Timur'un Semerkant'da oluşturduğu ortamdan gerçek anlamda torunları ve torunlarından dünyaya gelen mirzalar faydalanmıştır. Bilhassa Şahruh'un oğlu olan Uluğ Beğ Timur'un en şanslı torunu olarak bu ortamda yetişerek sadece âlimleri, şairleri, sanatçıları korumakla kalmamış kendiside âlim olarak eserler vermiştir (Babür, 1970:66). Uluğ Beğ'in astronomi bilgini olduğunu bilmekteyiz. Bunun yanı sıra tahta çıkmayıp ta ülkenin çeşitli bölgelerinde yöneticilik yapan Baysungur Mirza ve İbrahim Sultan gibi Timur'un torunlarının âlim ve sanatkârları himaye ettiğini bilmekteyiz (Thomas, 1985: 56). Ayrıca çok iyi bir hattat olan ve Herat'taki konağını o dönemin akademisi haline getiren, Baysunguri üslubunu oluşturan Mirza Baysungur, yetenekli şair olarak karşımıza çıkan Seyyit Ahmet, İskender ve Ebu Bekir mirzalar ile Hüseyin Baykar'a gibi birçok mirzanın ilim ve sanatçı olduğu bilinmektedir (Aka, 1991:109).

\section{Timur'un Bilim ve Kültüre Vermiş Olduğu Önemin Şehzadeler üzerinde Etkileri}

Timur siyasi birliğini tamamlar tamamlamaz fethettiği bölgelerdeki âlim ve bilgin insanları Semerkant'a getirtmiş ve buraları ilmi açıdan canlandırmaya çalışmıştır. Bu âlim kişiler arasında İbn Arabşah, Mehmet Asar b.Mehmet Cezeri, Siraceddin Muhammed b. Ömer Halebî gibi kişiler yer almaktadır (Barthold, 1901:108). İslam ve Türk-İslam hükümdarlarının bilimsel alanda uygulamış olduğu politikaları Timur da aynen takip etmiştir. Gerek İslam gerekse Türk İslam devletlerinin hükümdarları saraylar, medreseler ve rasathaneler yaptırarak âlim ve sanatkârları buralara davet ederek onlara her türlü desteği vererek bu bilim adamlarının ilimlerinden kendileri ve kendisinden sonra gelecek olan halefleri istifade etmiştir (İbn Arabşah, 1285:66). Timurlu hanedanlığının kurucusu olan Timur'un bilim adamlarına, âlimlere, sanatkârlara karşı sergilemiş olduğu himayeci tutum kendisinden sonra gelen haleflerini de etkileyerek artan bir şekilde devam etmiştir. Timur'a karşı olumsuz bir tavır sergileyen Arap kaynaklarının yanı sıra diğer kaynaklarda da Timur'un âlim ve din adamlarını herkesten üstünde tuttuğu ve meclislerinde kendilerine büyük değer verdiği bilinmektedir. Bu âlim adamlarla istişare ederek onların görüşlerini alarak herhangi bir konuda doğru bulmaya çalışırdı (ibn Arabşah, 1285:69). Sanatında usta olan herkese büyük değer verir onlara 
sahip çıkardı. Timur'un diğer İslam ve Türk İslam devletlerinden farklılığı da fethettiği ülkelerdeki meşhur âlim, bilim adamlarını ve sanatkârları zorla ülkenin başkenti olan Semerkant'a götürmesiydi (Yüksel, 2017:287). Böylelikle Semerkant, Buhara, Herat, Keş gibi büyük merkezler de medreseler inşa edilmiştir. Bu merkezler, medreselerin çokluğu ve bu medreselerde öğretim ve öğrenim yapmak için buralara gelen âlimler ve talebelere sağlanan imkânlarla ün salmıştır. Timur'un davet ettiği âlimler daha çok Semerkant'a toplanmıştır (Alan, 2004:153). Timurlularda medresenin ne zaman yapıldığı ve nerede kim tarafından yaptırıldığı kesin olarak bilinmemektedir (Tüzükat'ı Timurin ve Cengiz Yasası, 1974:111). Timur döneminde yaptırılan medreseler hanedan üyeleri olan ve geleceğin hükümdarı olacak olan şehzadelere göre tertip edilmiştir. Daha sonra diğer şehzadelere, hanımlara, vezirlere, beylere, âlimlere ve dönemin ileri gelen şahsiyetlerine göre düzenlenmiştir. Timurlu Devleti döneminde yaklaşık altmışa yakın medresenin olduğu bilinmektedir. Timurlular döneminde başta Timur olmak üzere oğulları, torunları, hanımları, vezirleri, beyleri ve zamanın âlim ve ileri gelenleri tarafından tabir yerindeyse her gittikleri bölgelere hatta köylere kadar medrese inşa ettirmişlerdir. Timur döneminde yaptırılan medreseler gerek eğitim gerekse mimari açıdan geçmiş dönemlerde yapılan medreselerin bir devamı gibi görünse de yapılan yeni düzenlemelerle karşımıza bir sentez olarak çıkmaktadır (Yüksel, 2001:66). Timurlular döneminde medreselerde genelde riyazî ve tabii bilimler okutulmaktaydı. Bu medreselere ülkenin çeşitli yerlerinden öğrenciler gelmekteydi. Timurlu medreselerinde hoca talebe ilişkileri devamlı surette hareket halindeydi (Eshenkulova, 2001:86). Ayrıca devletlerarası ilmi bir sirkülasyon vardı. XIV-XV. yüzyıllarda Timur ve Timurlu şehzadelerin himayesinde edebiyat, sanat, mimari alanda büyük gelişmeler meydana gelmiştir. Bu dönemde kültür ve sanat ve fikir hayatında çok mühim hamleler görülmektedir (Roemer, 1974:356). Resim, minyatür, müzik, edebiyat, heykeltıraşlık alanında o zamandaki çağın sanat hareketlerine hız vermişlerdir (Devletşah, 1977:417). Timurlular başta Arapça olmak üzere Farsça ve Çağatay Türkçesi olmak üzere üç dil kullanmaktaydı (Thackston, 1999:165). Arapça, eğitim görmüş herkes tarafından çok iyi bilindiği için İslam dünyasında en önemli bir dildi. Dini bilimlerden olan fıkıh, hadis, kelam, tefsir Arapça okutulmuş olup yine bu ilimlerle kaleme alınan eserler Arapça yazılmıştır (Taşköpri-zade, 1985:43). Maveraünnehir, Horasan ve İran bölgelerin dede Farsça edebi ve resmi bir dil haline gelmiştir. Timurlularla ilgili yazılmış olan ve Timurlu tarihiyle ilgili yazılar Farsça yazılmıştır. Timurlular döneminde Herat'ta büyük ve zengin bir kütüphane oluşturulmuştur. Bilim adamlarının ve sanatkârların meydana getirmiş olduğu eser- 
ler toplatılarak bu kütüphaneye konulmuştur. Bu eserler arasında hat ve minyatürle süslü Firdevs'inin 1420 yılında yazdığı Şahname adlı eseri oldukça önemli bir yer kaplamaktadır (Levent, 1967:515). Timurlular döneminde halk dili olan genelde Doğu Türkçesi diye bilinen günümüzde de Çağatay dili diye adlandırılan bu dil o dönemde orta seviyede edebi bir dil olarak kullanılmaktaydı. Bu dil önce Moğol döneminden kalma Uygur alfabesi daha sonrada Arap alfabesiyle yazılmıştır. Şahruh Mirzanın 1422 yılında yazdığı eser olan Suyurgul Uygur alfabesi ile Çağatay Türkçesinde kaleme alınmıştır (Aka, 1994:213). Çağatay şiir sanatının Herat'ta geliştiğini görmekteyiz. Bu dilin gelişmesinde Ali Şir Nevai'nin büyük katkılarının olduğuda bilinmektedir. Bu katkılardan dolayı Çağatay Türkçesine "Nevai Dili" de denilmektedir. Ali Şir Nevai'ye göre Timurlu hanedanından olanlardan Hail Sultan, Sultan İskender Şirazi,Uluğ Beğ, Baysungur, Babur Mirza, Abdullatif Mirza, Cihan şah Mirza, Seyyid Ahmed Mirza, Sultan Ahmed Mirza, Yakup Mirza, Hüseyin Baykara, Küçük Mirza, Şah Garib Mirza, Sultan Beddüzzaman'larda şiirler yazmış ve matla söylemişlerdir (Ali Şir Nevai, 1995:186).

\section{Sonuç}

Daha önceki Türk devletlerinde olduğu gibi Timurlularda da devletin ülke hanedan ailesinin ortak malı kabul ediliyordu. Dolayısıyla hanedan ailesine mensup her erkek evladın tahta çıkma hakkı vardı. Geleceğin hükümdarları olacak şehzadelerin (Mirzaların) eğitimine oldukça önem verilirdi. Şehzadelere bu eğitim verilirken şehzadeler arasında bir ayırım yapılmazdı. Şehzadelerin eğitimi devlet görevi sayıldığı için şehzade doğar doğmaz annesinden alınarak doğan şehzadenin kız erkek fark etmez bakımı, eğitimi için erkek çocuklarına atabey kız çocuklarına (ateke) atabey atanırdı. Şehzadelerin eğitimi önce saraylarda başlardı. Buralarda atabeylerin eşliğinde dini ve akli bilimlerle ilgili dersler verilirdi. Belli bir yaşa geldikten sonra tecrübeli ve eğitimli atabeyleriyle birlikte eyalet merkezlerine geleceğin hükümdarı olarak yetişmesi için gönderilirdi. Gittikleri eyalet merkezlerinde şehzadeler merkezdeki saray ve idari teşkilatı aynen buralarda oluşturulurdu. Şehzadelerin gönderildikleri eyaletlerde gerek şehzadeler arasında gerekse atabeyleri arasında herhangi bir şekilde anlaşmazlık hâsıl olursa bu anlaşmazlığa ancak hanedanın başında olan hükümdar müdahale ederdi. Yapılan incelemeler sonucunda hangi taraf haksız bulunursa o tarafa ceza verilirdi. Timur kendi haleflerine çok önem vermekteydi. Genellikle mirzaların suçu görmezlikten gelir veya zorunlu durumlarda onlara hafif cezalar vermeye çalışırdı. Bu cezalandırma şekilleri genelde sopa attırmak, huzuruna belli bir süre kabul etmemek gibi hafif ceza- 
lardı. Ancak kendisinden sonra halefleri döneminde bu cezalar ağırlaştırılarak ölüm cezalarına kadar gitmiş̧tir. Timur daha sağlı̆ı̆ındayken öldüğüne dair iki defa asıısız haberler çıkartmıştır. Ölümünden sonra devletin içerisinde çıkması muhtemel ayaklanmalara karşı tedbir almak için kendisinden sonra devletin başına Mirza Pir Muhammed'i veliaht tayin etmiş ise de bu vasiyetine uyulmamıştır. Mirzaların eyaletlere gönderilme geleneğinden Şahruh döneminden itibaren vazgeçildiği ve iki oğlu olan Abdurrahman ve Abdülaziz'in babalarının yanında Semerkant Sarayında yetiştiği bilinmektedir. Timur'un ölümü hanedanlar arası büyük taht mücadelesinin ortaya çıkmasına neden oldu. Timur'un kurmuş olduğu sağlam devlet yapısı hanedanları mirzaların (şehzadeler) arasında yaşanan iç çekişmeler ve hâkimiyet mücadeleleri sonrası yıpranmış ve yıkılmıştır. Doğuda Hindistan ve Çin'den, batıda Anadolu ve Suriye'ye kadar uzanan büyük bir coğrafyada yaklaşık 137 yıl hâkim olan Timurlu Devleti'nde bütün daha önceki Türk devletlerinde olduğu gibi belli bir veraset anlayışının olmaması mirzalar(şehzadeler) arasında mücadeleler ve devletin yıkılmasına ve çöküşünü neden oldu. Timur öldükten sonra atabeylerin kendi başına buyruk hareket etmeleri, kendi adlarına para bastırmaları, bağımsızlıklarını ilan etmeleri ve mirzaların eğitiminde etkili olmaması devletin ömrünü kısalttı. Mirzaların sarayda eğitim görmeleri tecrübe kazanmadan başa geçmelerine, şehzadelerin yönetimde tecrübesiz olarak saraydan çıkmadan bir devleti yönetmeleri ve halkın sorunlarını tam olarak kavrayamamaları devletin yıkıışını hızlandırmışıı. Ayrıca Timurlu devletinin hükümdarları ve mirzalarının eğitime önem vererek Türk-İslam bilim, sanat ve kültür geleneğine büyük katkılar sağlamışlardır. Timurlu Devleti ile ilgili birçok çalışmalar yapılarak o döneme ait birçok alanda araştırmalar yapıımış ve kaleme alınmıştır. Sonuç olarak şunu söyleyebiliriz ki bu çalışmamızla Timurlulardaki şehzade eğitimi ele alınarak bu alanda eksik kalan boşluğa bir nebze de olsa ışık tutmaktır. 


\section{Kaynakça}

Aka, İsmail. (1991). Timur ve Devleti, Ankara: Türk Tarih Kurumu Basımevi.

Aka, İsmail.(1994). Mirza Şahruh ve zamanı (1405-1447), Ankara: Türk Tarih

Kurumu Basımevi.

Aka, İsmail.(2001). İran'da Türkmen Hâkimiyeti( Kara Koyunlular Devri), Ankara: Türk Tarih Kurumu Yayınları.

Aka, İsmail.(2012). "Timurlular", Türk İslam Ansiklopedisi, C.41: 177-180.

Alan, Hayrunnisa. (2004). "Timurluların Bilim ve Sanata Yaklaşımları ve Bazı

Son Dönem Sanatkârları," Bilig, 30:151-171.

Ali Şir Nevai. (1995). Mecalisu'n- Nefois, (Haz. H.Ayan, K. Yavuz, E. Gemal-

maz, R. Toparlı, G.Ayan, Y. Akpınar, (latin alfabesine transkipsiyonu),

Erzurum.

Babur.( 1970) Baburname (çev. Reşit Rahmeti Arat), İstanbul: MEB Yayınları.

Barthold, Wilhelm. (1997). Uluğ Beğ ve Zamanı, Ankara: Türk Tarih Kurumu.

Barthold'd, Wassiliy W.(1901). "Timuridi”, Ensiklopediçesky slovar, C.XXXIII (edt. Efron Brokgauz), Saint-Petersburg: 195-197.

Bıyıktay, Halis. (1989). Timurlular Zamanında Hindistan Türk Imparatorluğu,

Ankara: Türk Tarih Kurumu Yayınları.

Clavijo, Ruy Gonzales de. (1881). La viday hazanas del gran Tamorlan, (ter.

Sreznevsky,st.) Petesburg. Timur Devrinde Kadis'ten Semerkant'a Se-

yahat, (Ter. Ömer Rıza Doğrul). Tarihsiz.

Clavijo, Ruy Gonzales de.(1993). Anadolu'da, Orta Asya ve Timur, (çev.

Ö.Rıza Doğrul), İstanbul: Ses Yayınları.

Devletşah.(1977). Tazkirat al- Şuara (çev. Necati Lugal), İstanbul.

Eshenkulova, Kishimjan.(2001). Timurlular Devri Medrese Eğitimi Ve Ulum El-

Eva'il (Matematik, Astronomi Ve Tıp, Basılmamış Yüksek Lisans Tezi.

İbn Arabşah.(1285). Acaibü'l Makdur fi Ahbar Teymur, Kahire.

İbn Arabşah.(1285). Kıtab acaibu'l- makdur fi ahbar Timur, Kahire.

Kafalı, Mustafa. "Timur", IA, XII/1 :336-346.

Levent, Agâh Sırrı. (1967). Ali Şir Nevai Hamse, C.III, Ankara: Türk Tarih Kurumu Yayınları.

Levy, R.(1993). “Mirza” El VII, Leiden, New York: 129-220.

Mansura, Haider. (1984). "Timurlular Devletinde Hâkimiyet Anlayışı", (çev.

Ekrem Memiş), Türk Kültürü- Türk Kültürü Araştırma Enstitüsü, XXII/XXV, Ankara: 611-632. 
Nizameddin Şami. (1949). Zafername, (çev. Necati Lugal), Ankara.

Roemer, Hans R. (1974). "Timurlular”, IA, C.12/1, MEB Yayınları: 346-370.

Şerefüddin Ali Yezdi.(2013). Emir Timur (Zafername),(çev.D. Ahsen Batur), İstanbul: Selenga Yayınları.

Şimşirgil, Ahmet. (2017). Emir Timur II Otağ, İstanbul: Timaş Yayınları.

Taşköpri-zade. (1985). al- Şaka'ik al-Nu maniyya fi 'Ulema' al-Davlat al- 'Osmaniyya (Haz. Ahmed Suphi Furat), İstanbul: IÜEF Yayınları.

Thackston,W.M. (1999).“Timurids”, El, New Edition , vol. X, Leiden- Brill: 516517.

Togan, Zeki Velidi. (1946). “Büyük Türk Hükümdarı Şahruh”, TDED,III/3-4, s.520-538.

Togan, Zeki Velidi. (1972). "Emir Timur'un Soyuna dair Bir Araştırma”, (çev. İsmail Aka), Tarih Dergisi, S.26: 75-84.

Togan, Zeki Velidi.(1932). “Temur Bek'in İslamiyet'e Bakışı,” XIII, Atsız Mecmua: 7-11.

Tüzükat-ı Timurin ve Cengiz Yasası. (1974). (Haz. Alemdar Yalçın), İstanbul.

Yücel, Yaşar.(1989). Timur'un Ortadoğu- Anadolu Seferleri ve Sonuçları (1393-1402), Ankara: Türk Tarih Basımevi.

Yüksel, Musa Şamil. (2001). El-Makrizi (Kitab Es-Suluk) Ve İbn Hacer (İnba'el-Gumr)'De Timur İle İlgili Kayıtlar Ve Çağdaşı Arap Tarihçilerine Göre Timur Tasviri, Basılmamış Yüksek Lisans Tezi.

Yüksel, Musa Şamil. (2009). Timurlularda Din-Devlet Ilişkisi, Ankara: Türk Tarih Kurumu Basımevi.

Yüksel, Musa Şamil. (2014). “Timurlu Sarayında Cereyan Eden İlmi Münazaralar, El- Cezeri ve Et- Taftazani Örneği”, Tarihin ve Tarihçinin İinden Kazım Yaşar Kopraman Armağanı, Ankara: 117-124.

Yüksel, Musa Şamil.(2017). "Ortaçağlarda Beyin Göçü ve Etkileri: Timurlular Örneği”, OTAM, 41: 283-302. 


\section{Prince Training in Tamerlane}

Citation / (O-- Şahbaz, M. (2018). Prince Training in Tamerlane, Çukurova University Journal of Faculty of Divinity, 18 (1), 313-328.

Abstract- Turkish-Mongol and Timurid Iran with native elements that have occurred as a result of mixing of Islamic culture, they confront us with a structure their own. Tamerlane although Jagatai tradition, especially Cengiz and sustains the steppe the tradition of Turkish organizations, Arab and Muslim emerged as a separate structure from the Turkish government though has also grown in the Turkish-Islamic culture and Maveraunnehir the tradition of dominant. Timur ruling legitimacy and dominance has been shaped by understanding while revealing on Turkish sovereignty understanding. As with other Turkish and Mongolian State Sovereignty it has maintained the Turkish universe understanding. Timurid State of the Turkish forces in accordance with the traditional understanding of sovereignty as well as to accept the Islamic religion was directly the right to receive from God. God's shadow on earth and as a most competent authority after the Islamic prophet himself as an absolute authority to protect the public and religious authorities are using the power of this confronts us. After the selfunderstanding of sovereignty in this time Tamerlane has continued his successors. Where is the priority of this study as Tamerlane, when and by whom it was founded, timely Timur created Timurid state policy should be in line with the Prince (of Mirza) education were discussed. Tamerlane gave great importance to the education of the princes and members of the dynasty. So have accepted this tasks as a state duty and have implemented and education system starting from birth to princes and members of dynasty. This is where the education system and Princes do that which passes through the process and teachers allocated to the Prince of princes and their impact on teacher education process of these have been studied. Birth of Mirza throne, the role of education in Atabey processes and tasks are handled. In addition, the Timurid ruler and prince of science, education and culture, including Samarkand, Herat emphasis primarily to the lands they dominated, Shiraz, cities such as Tabriz are dealt with to make science and arts center.

Keywords- Mirza, education, Timurid State, state administration, atabey 